\title{
Retraction
}

\section{Retracted: Risk Factors of Periodontal Disease: Review of the Literature}

\author{
International Journal of Dentistry
}

Received 25 January 2021; Accepted 25 January 2021; Published 15 February 2021

Copyright (C 2021 International Journal of Dentistry. This is an open access article distributed under the Creative Commons Attribution License, which permits unrestricted use, distribution, and reproduction in any medium, provided the original work is properly cited.

International Journal of Dentistry has retracted the article titled "Risk Factors of Periodontal Disease: Review of the Literature" [1]. Since the publication of the article, a significant amount of overlap has been identified with existing publications. The significant sources are listed in the references as [2-5].

The author was asked for clarification but did not provide a response. It is therefore being retracted with the agreement of the editorial board.

\section{References}

[1] Y. A. AlJehani, "Risk Factors of Periodontal Disease: Review of the Literature," International Journal of Dentistry, vol. 2014, Article ID 182513, 9 pages, 2014.

[2] D. F. Kinane and T. C. Hart, "Genes and Gene Polymorphisms Associated with Periodontal Disease," Critical Reviews in Oral Biology \& Medicine, vol. 14, no. 6, pp. 430-449, 2003.

[3] S. Ajwani, Periodontal Disease in an Aged Population, and Its Role in Cardiovascular Mortality, University of Helsinki, Helsinki, Finland, 2003, https://helda.helsinki.fi/handle/10138/ 20274.

[4] L. G. Do, "Smoking and Periodontal Disease in Vietnamese Middle-Aged Population," MSc Thesis, University of Adelaide, Adelaide, Australia, 2001, https://digital.library.adelaide.edu. au/dspace/handle/2440/37770.

[5] G. E. Salvi, H. P. Lawrence, S. Offenbacher, and J. D. Beck, "Influence of Risk Factors on the Pathogenesis of Periodontitis," Periodontology 2000, vol. 14, no. 1, pp. 173-201, 1997. 